\title{
Vénafalhoz szívósan szervülő centrális vénás hemodialíziskatéter eltávolítása endovascularis technikával
}

\author{
Juhász Viktória dr. ${ }^{1}$ - Dósa Edit dr. ${ }^{1}$ - Oláh Zoltán dr. ${ }^{1}$ \\ Szabó József dr. ${ }^{2}$. Szeberin Zoltán dr. ${ }^{1}$ \\ Semmelweis Egyetem, Általános Orvostudományi Kar, Városmajori Szív- és Érgyógyászati Klinika, \\ Érsebészeti Tanszék, Budapest \\ ${ }^{2}$ Semmelweis Egyetem, Általános Orvostudományi Kar, Transzplantációs és Sebészeti Klinika, Budapest
}

\begin{abstract}
A hemodialízisre szoruló, krónikus veseelégtelenségben szenvedő betegek száma évről évre növekszik, aminek következtében egyre gyakrabban kerül sor tartós centrális vénás dializálókanülök beültetésére. A kanülök hosszú idejü alkalmazásakor - a kialakuló fibrinhüvely miatt - a későbbi eltávolításuk nehézségekbe ütközhet. Egy új, minimálinvazív intervenciós radiológiai módszerrel (úgynevezett Hong-technikával), kis feltárásból végzett endoluminalis tágítással a vénafalhoz, illetve a jobb pitvarhoz szívósan tapadó katéterek mellkasnyitás nélkül távolíthatók el. Hazánkban először vettünk ki ezzel a technikával egy 6 évig használt és a szokásos módszerekkel nem eltávolítható dializálókanült a bal vena subclaviából. Tapasztalatunk alapján javasolható a Hong-technika rutinszerű alkalmazása.

Orv Hetil. 2019; 160(11): 435-437.
\end{abstract}

Kulcsszavak: krónikus veseelégtelenség, hemodialízis, endovascularis, centrális vénás kanül

\section{Endovascular removal of a hemodialysis catheter stuck in central vein}

The number of patients with end-stage kidney disease requiring hemodialysis has been growing. The use of permanent central venous dialysis catheters has been increasing. Catheters in the central veins may adhere strongly to the vessel wall, so their removal may lead to difficulties. A recently published endovascular method (so-called Hong technique) turns the catheter removal to an easy and fast outpatient method and avoids sternotomy. We successfully removed a catheter inserted into the left subclavian vein 6 years ago which was impossible to extract by the usual techniques. Based on our experience, we recommend the routine use of the Hong technique.

Keywords: chronic kidney disease, hemodialysis, endovascular, central venous catheter

Juhász V, Dósa E, Oláh Z, Szabó J, Szeberin Z. [Endovascular removal of a hemodialysis catheter stuck in central vein]. Orv Hetil. 2019, 160(11): 435-437.

(Beérkezett: 2018. szeptember 20.; elfogadva: 2018. október 13.)

\section{Rövidítés}

TCVK = tunelizált centrálisvéna-katéter

A krónikus veseelégtelenség napjainkban egyre gyakoribb; világszerte a felnőtt lakosság 10-16\%-át érinti. A végstádiumú vesebetegségben szenvedő betegek száma és a hemodialízisre szorulók aránya is évről évre nő [1]. Az egyre idősebb, vesepótló kezelést igénylő betegeknél a tartós vérnyerési hely kialakítása gyakran okoz nehézséget. Az arteriovenosus fisztula éréséig, áthidaló megoldásként - míg meglévő fisztula elzáródásakor, illetve amikor megfelelő fisztula kialakítására nincs lehetőség definitív megoldásként tunelizált centrálisvéna-katétert (TCVK) helyezünk be. A TCVK hosszú idejü alkalmazása esetén a katéter és a vénafal között kialakuló fibrines összetapadás és az esetlegesen társuló vénaszúkület miatt azonban eltávolítása gyakran nehézségekbe ütközik [2]. 
Ilyen esetekben a katéter kivételéhez a nyitott mütéti (sternotomia), komplex endovascularis vagy lézeres módszer mellett a nemrégiben leírt és Hong-technika néven elterjedt endoluminalis minimálinvazív módszer nyújthat segítséget [3]. Az endoluminalis tágítás során a dializálókatéter lumenében felfújt ballon a lumenátmérő növelésével és a katéter falának feszülésével megszakítja a környező fibrines összenövéseket, így a katéter könnyen eltávolíthatóvá válik. Tudomásunk szerint Magyarországon elôször alkalmaztuk ezt az alább bemutatott minimálinvazív, kontrasztanyag-terheléssel nem járó, ambulánsan kivitelezhető endovascularis technikát egy olyan betegnél, akinek a szokásos módszerekkel nem eltávolítható dialíziskanülje volt. A Hong-technika hasonló esetekben más betegeknél is jó megoldás lehet.

\section{Esetbemutatás}

Egy 57 éves férfi betegnél gastroenteritis kapcsán kialakult akut veseelégtelenség miatt 2012-ben kétszárú BioFlex Tesio katéter (Medical Components Inc., Harleysville, PA, Egyesült Államok [USA]) került behelyezésre a bal vena subclaviába. A beteg tartósan dialízisre szorult; a kanülön át 6 éven keresztül heti háromszor szövődménymentesen hemodializálták, majd 2018 márciusában sikeres kadávervese-transzplantáción esett át. Négy hónappal később megfelelő vesemúködés mellett megkísérelték a fertőzésmentes katéter helyi érzéstelenítésben történő eltávolítását, ez azonban a mandzsetta átvágása és a tunel megszüntetése ellenére sem sikerült. A katéter érsebészeti eltávolítása érdekében a beteget intézetünkbe, a Semmelweis Egyetem Városmajori Szív- és Érgyógyászati Klinikájára irányították. A beteg a bal kulcscsontja felett metszett, körülbelül $3 \mathrm{~cm}$-es hosszúságú sebben lefogott két átvágott kanülszárral érkezett osztályunkra (1. ábra), melyek a vena cava superiorban, illetve a jobb pitvarban végződtek (2. ábra). A katéter kézi erővel történő eltávo-

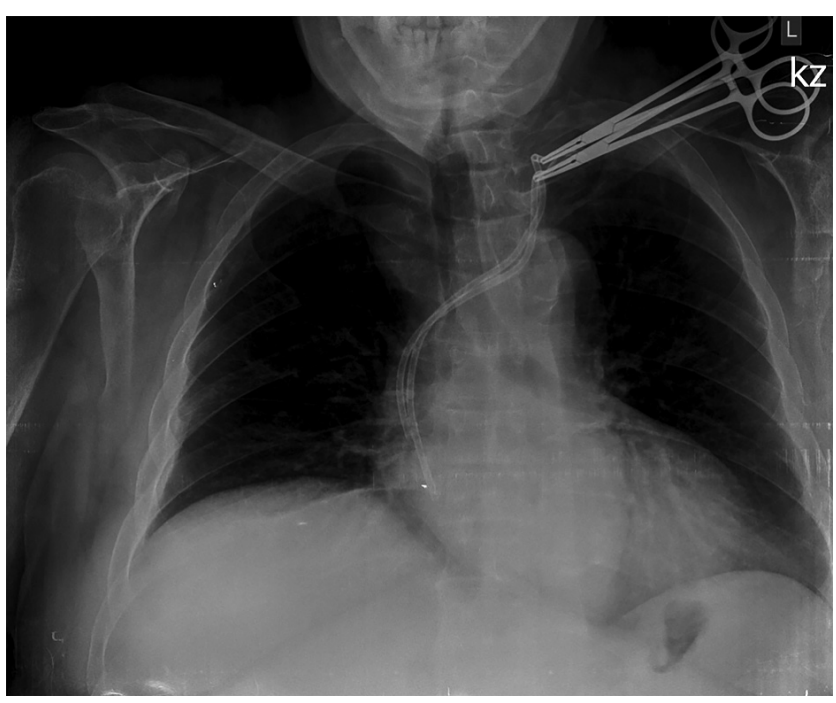

1. ábra $\quad$ Preoperatív állapot. A bal kulcscsont feletti feltárás sebében lát hatók a lefogott katéterszárak

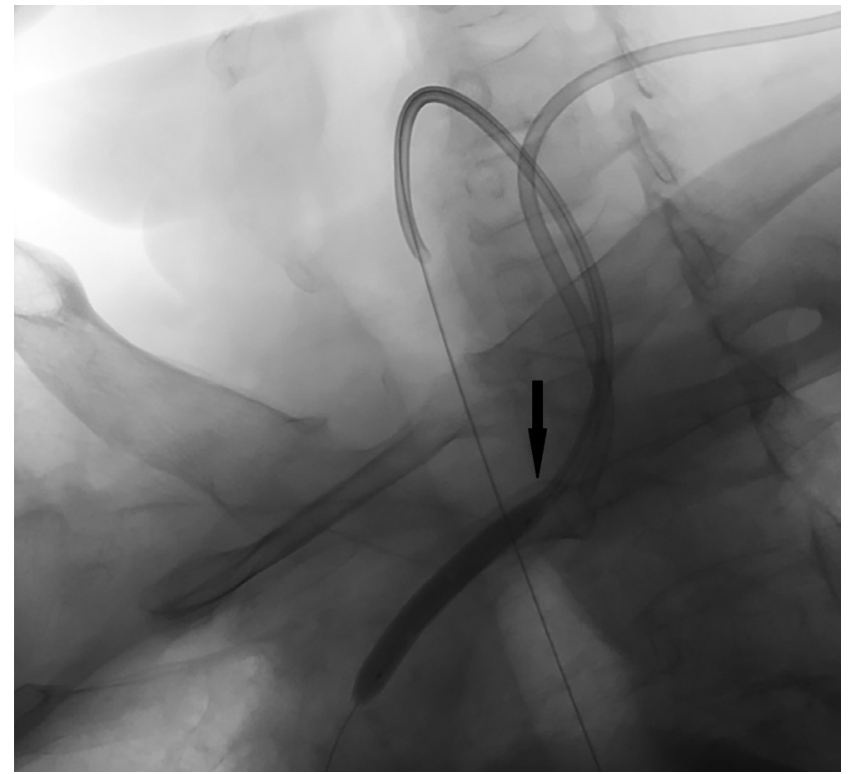

2. ábra

Anteroposterior mellkasröntgen-felvétel. A képen a bal vena subclavián keresztül bevezetett dialíziskanül figyelhető meg, melynek szárai a vena cava superiorban, illetve a jobb pitvarban végződnek

lítását intézetünkben ismételten megpróbáltuk, ez azonban a kiterjedt heges összenövések miatt csak a kanül elszakadását vagy a véna, illetve a pitvar falának esetleges fatális sérülését kockáztatva lett volna kivitelezhető, így ettől elálltunk. A katéter narkózisban végzett, mellkasmegnyitást igénylő mútéti eltávolítása nagy perioperatív rizikóval, potenciális posztoperatív intenzív osztályos kezeléssel járt volna, emiatt inkább a Hong által leírt és az irodalom alapján több alkalommal mások által már sikeresen alkalmazott [4,5] minimálinvazív endovascularis módszert választottuk. Röntgen-képerősítő alatt előbb az egyik, majd a másik kanülszárba egy V-18-as vezetődrótot (V-18 Control Wire, Boston Scientific Corp., Natick, MA, USA) vezettünk be, majd $5 \mathrm{~mm}$-es átmérőjü, 40 mm-es hosszúságú ballonokkal (Passeo-18 5/40/90, Biotronik AG, Bülach, Svájc) a kanülök teljes hosszában, ballonfelfújásonként $1-1$ percig tartó tágítást végeztünk (3. ábra). Ezt követően a katéterszárak lassú, de erőteljes húzóerő kifejtésével egyenként eltávolíthatóvá váltak (4. ábra). A 15 percig tartó, kontrasztanyag-terheléssel nem járó beavatkozás során 47 mGy belépő sugárdózist alkalmaztunk. A teljes fluoroszkópiás sugáridő 4,3 perc volt. A katéter sikeres eltávolítása után a kulcscsont feletti feltárás sebét két csomós öltéssel zártuk. Kontrollechokardiográfián szövődményre utaló kóros mennyiségü pericardialis folyadékgyülem nem ábrázolódott. A beteget a beavatkozás után néhány órával panaszmentesen otthonába bocsátottuk.

\section{Megbeszélés}

A TCVK hosszú idejü alkalmazása esetén a katéter és a vénafal között kialakuló fibroticus folyamat következté- 


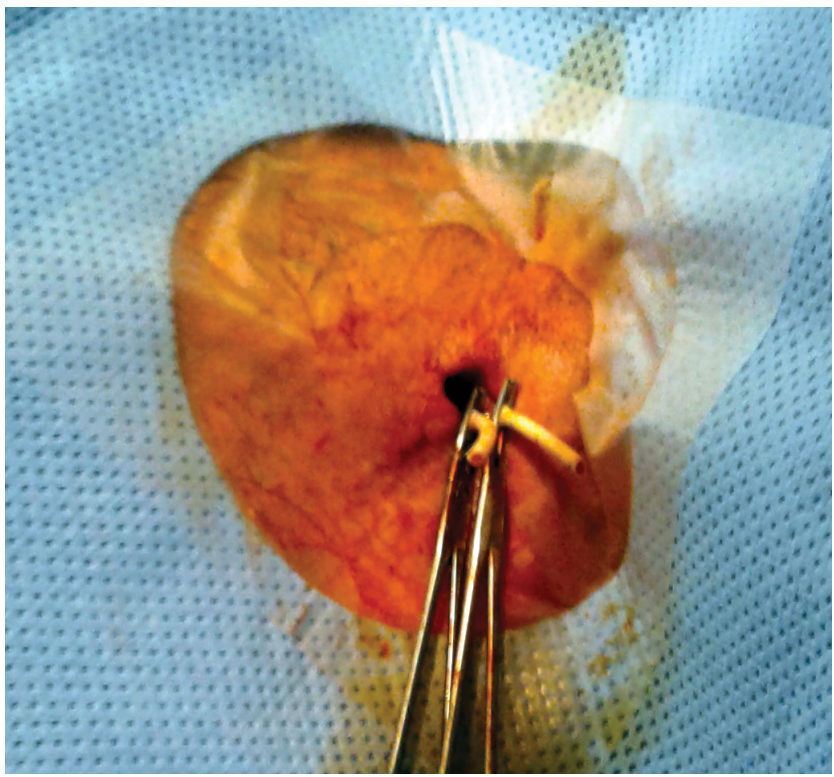

3. ábra

Intraoperatív kép. Ezen az ábrán a Tesio kanül szárába vezető dróton keresztül bevezetett és felfújt, $5 \mathrm{~mm}$ átmérójű, $40 \mathrm{~mm}$ hosszúságú ballon ábrázolódik

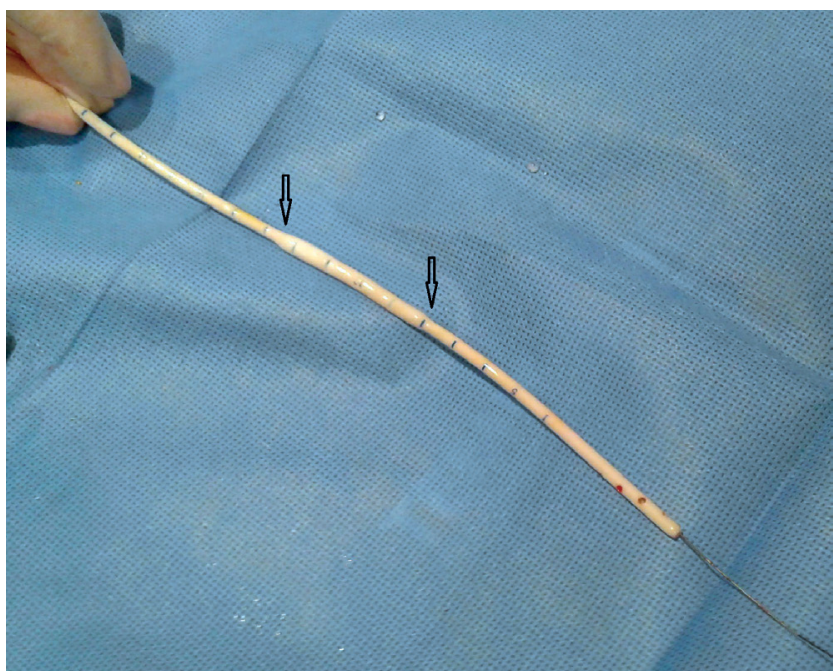

4. ábra Az eltávolított dialíziskanülben ex vivo felfújt $5 \mathrm{~mm}$ átmérójü
ballon látható. A nyilak a felfújt ballon két végére mutatnak

ben a katéter későbbi kivétele gyakran nehézséget okoz. Az eltávolítást a társuló centrálisvéna-szúkület vagy -elzáródás tovább nehezítheti. Az infekt kanülök kivétele általában nem jelent nehézséget a hagyományos technikákkal (bőr alatti mandzsetta eltávolítása és kanül kihúzása lokálanesztéziában kis nyaki metszésből). A lézeres fibrinhüvely-felszabadítás drága módszer, mely általános anesztéziát és egy, a technikában jártas szakembert igényel, valamint jelentős szövődményekkel is járhat, míg a mellkasnyitással vagy sternotomiával járó nyitott mútéti eljárások fokozott perioperatív morbiditással és mortalitással bírnak. Az utóbbi évtizedben az intervenciós radiológia technikai fejlődésének köszönhetően számos új módszer került leírásra a vénafalhoz szervülő centrális vénás katéterek minimálinvazív eltávolítására. A kezdeti, vénafalon belül, de katéteren kívül végzett komplex fibrinhüvely-megszakító módszerek után a 2011-ben Hong által leírt [3], egyszerúen kivitelezhető, katéteren belüli, endoluminalis ballonos technika terjedt el. A módszer szövődmények nélküli, egyszerü használatát más szerzők is megerósítették $[4,5]$. Az irodalomban egy esetben számolnak be a ballon felfújását követően a katéter falának megrepedéséról [6]. Esetünk is igazolja, hogy a módszer segítségével a vénafalhoz szívósan tapadó dializálókanülök gyorsan, biztonságosan, alacsony anyagköltséggel, kontrasztanyag-terhelés és általános anesztézia nélkül ambulánsan is eltávolíthatók. Tapasztalatunk alapján javasoljuk a módszer szélesebb körű használatát invazív vascularis radiológiai és érsebészeti háttérrel rendelkező intézményekben.

Anyagi támogatás: A közlemény megírása anyagi támogatásban nem részesült.

Szerzői munkamegosztás: J. V.: A kézirat megírása. D. E.: A beteg kezelése, a képdokumentáció elkészítése. O. Z.: A beteg kezelése, a kézirat megírása. Sz. J.: A beteg kezelése, a kézirat ellenőrzése. Sz. Z.: A kézirat megírása, ellenőrzése. A cikk végleges változatát valamennyi szerző elolvasta és jóváhagyta.

Érdekeltségek: A szerzőknek nincsenek érdekeltségeik.

\section{Irodalom}

[1] Nagy J. The chronic kidney disease "epidemy". [Krónikus vesebetegségek „epidémiája”.] Orv Hetil. 2013; 154: 43-51. [Hungarian]

[2] Field M, Pugh J, Asquith J, et al. A stuck haemodialysis central venous catheter. J Vasc Access 2008; 9: 301-303.

[3] Hong JH. A breakthrough technique for the removal of a hemodialysis catheter stuck in the central vein: endoluminal ballon dilatation of the stuck catheter. J Vasc Access 2011; 12: 381384.

[4] Ryan SE, Hadziomerovic A, Aquino J, et al. Endoluminal dilatation technique to remove "stuck" tunneled hemodialysis catheters. J Vasc Interv Radiol. 2012; 23: 1089-1093.

[5] Quaretti P, Galli F, Fiorina I, et al. A refinement of Hong's technique for the removal of stuck dialysis catheters: an easy solution to a complex problem. J Vasc Access 2014; 15: 183-188.

[6] Forneris G, Savio D, Quaretti P, et al. Dealing with stuck hemodialysis catheter: state of the art and tips for the nephrologist. J Nephrol. 2014; 27: 619-625.

(Juhász Viktória dr.,

Budapest, Városmajor u. 68., 1122 e-mail: drjuhasz.viktoria@gmail.com)

A cikk a Creative Commons Attribution 4.0 International License (https://creativecommons.org/licenses/by/4.0/) feltételei szerint publikált Open Access közlemény, melynek szellemében a cikk bármilyen médiumban szabadon felhasználható, megosztható és újraközölhető, feltéve, hogy az eredeti szerző és a közlés helye, illetve a CC License linkje és az esetlegesen végrehajtott módosítások feltüntetésre kerülnek. (SID_1) 